Margareta Ekborg is a senior lecturer at Malmö University, School of Teacher Education. Her research interest is socioscientific issues and scientific literacy. She has a special interest in environmental education.

Mats Areskoug is associate professor in Physics, particularly Physics Education, at Malmö University. He has a special interest in environmental physics, developing course books experiments and teaching methods within the field.

MARGARETA EKBORG

Malmö University, School of Teacher Education, Sweden

margareta.ekborg@educ.umu.se och margareta.ekborg@lut.mah.se

MATS ARESKOUG

Malmö University, School of Teacher Education, Sweden

mats.areskoug@lut.mah.se

\title{
How student teachers' understanding of the greenhouse effect develops during a teacher education programme
}

\begin{abstract}
This paper reports on a longitudinal study on how student teachers' understanding of the greenhouse effect developed through a teacher education programme in mathematics and science for pupils aged 7-13. All student teachers, who were accepted to the programme one year, were followed trough 2.5 years of the programme. The student teachers took science courses in which they were taught about the greenhouse effect.
\end{abstract}

Data was collected by questionnaires three times. The results show that a majority of the student teachers developed an adequate understanding of the greenhouse effect during the teaching programme. Several of the students developed further in the second science course. However a rather big group of students with poor understanding did not develop any further in the second science course and no one demonstrated full understanding. Different ways of collecting data and categorising responses affected how the students' understanding was interpreted.

\section{INTRODUCTION}

One major environmental problem extensively discussed in media is the enhanced greenhouse effect. It was recognised as one of thirteen major global issues at the 1992 Earth Summit in Rio de Janeiro. After Rio there have been several attempts to work out international policy documents on climate change. The Kyoto protocol was adopted in 1997. Several countries have signed and ratified the protocol while the USA for example has signed it but not ratified it. A reason why it has been so difficult to come to an agreement about how to act concerning climate change is that the issues are very complex. They include knowledge from several subject areas, and there is no scientific agreement on to what extent different processes contribute. Furthermore, values are involved in judging the causes and effects and in deciding the best actions to take. The issues contain conflicting interests on several levels. On an international level, nations have different infrastructures, natural resources, and geographic situations, political situation etc, which make them argue and act in different ways. Also within countries and regions there are different interests in how for example traffic and transportation are organised. 
To be able to follow and participate in the debate concerning the effects of fossil fuels on climate, you need to understand the issues, to be able to make decisions and articulate your opinion and act in accordance with this. Several curricula and policy documents for schools in Europe and elsewhere highlight the importance of developing pupils' skills in decision-making on the basis of sound science (QCA; Skolverket, 2000). Teachers, of course, then have an important role and teacher education is therefore crucial.

\section{AIM OF THE STUDY}

The aim of the study, reported in this paper, is to provide evidence about how student teachers' learning about the greenhouse effect develops during their initial training. Another aim is to discuss how the categorising methods affect the interpretation of responses. The research question is "How did student teachers' conceptions of the greenhouse effect develop during the teacher education programme?"

\section{Previous RESEARCH}

Most studies concerning conceptions about the greenhouse effect are short-term studies performed with pupils in school. A major result is that pupils know about global warming and the greenhouse effect but both their factual knowledge and their conceptual understanding are incomplete and often misleading (Rickinson, 2001). There are a number of British studies (Boyes \& Stanisstreet, 1992, 1993, 1997, 1998) in which pupils' perceptions of the greenhouse effect have been examined. The studies are quantitative and include a large number of subjects. The pupils gave their view of a number of statements concerning the greenhouse effect by indicating whether the statements were correct or not. The researchers found that many pupils know basic facts about the greenhouse effect. Most pupils anticipate the idea that the earth gets hotter, that global weather patterns will change and that polar ices will melt if the greenhouse effect increases. The number of pupils who ticked the statements correctly increased with age. But many pupils of all ages believe that holes in the ozone layer will cause an enhanced greenhouse effect. This has also been observed by others, e.g. Andersson and Wallin (2000), Dove (1996), Mason and Santi (1998). Boyes and Stanisstreet (1998) suggest that the problems of distinguishing between the greenhouse effect and ozone depletion may be due to problems in distinguishing IR radiation from UV radiation or even radiation from thermal energy. Many pupils believe that the energy release (not the carbon dioxide) from cars' engines is the reason for global warming (Boyes \& Stanisstreet, 1997).

Similar studies (Boyes \& Stanisstreet, 1992 and Boyes, Chambers \& Stanisstreet, 1995) also investigated university students' ideas about the greenhouse effect. 218 students, aged 18-20, were enrolled in an introductory course for biology studies. The students held the same kind of misconceptions as the children, concerning for example the role of ozone depletion and lead free petrol, but to less extent. A study by Jefferies, Stanisstreet and Boyes (2004) investigated university students' understanding of the greenhouse effect 10 years after the previous studies in order to see if the situation has improved. However, if there was any change, more students held misconceptions in the later study than in the first one.

Dove (1996) examined how well 60 students in the first and second year of a Bachelor of Education programme understood the greenhouse effect, depletion of the ozone layer and acid rain. There were some open-ended questions but basically the students agreed or disagreed with a number of statements. The results about the greenhouse effect verified the results obtained by Boyes and Stanisstreet (1992).

Khalid (2003) showed that also among American pre-service high school teachers many misconceptions concerning the greenhouse effect, the depletion of the ozone layer and acidification are 
present. He adopted 30 statements from the survey conducted by Dove (1996). 27 student teachers got five choices to respond to and they were invited to comment the answers. Most students knew that carbon dioxide is the most abundant gas responsible for the enhanced greenhouse effect and that the temperature in the USA will rise if the greenhouse effect increases. But a majority also indicated that holes in the ozone layer would enhance global warming and that an enhanced greenhouse effect will result in more people getting skin cancer.

In all studies it was shown that there is better understanding of the ozone layer than of the greenhouse effect and it is common to confuse the greenhouse effect with the depletion of the ozone layer. It was also found that many pupils and students have naive ideas about environmental problems. For example there is a tendency to believe that environmentally friendly actions are good to all environmental problems.

\section{MODELS AND CATEGORIES}

In a study in Sweden 201 pupils in grade 9 (age 15) and 229 pupils in grade 12 (age 18) were asked to describe in their own words what the greenhouse effect is (Andersson \& Wallin, 2000). A number of models, describing how the greenhouse effect can be understood, were identified. They are on display in table 1. In the paper by Andersson and Wallin (2000) there are subcategories which are excluded in this simplified table. The categorisation is based on understanding of the difference between incoming and outgoing radiation which explains the greenhouse effect. It is noteworthy that only $5 \%$ of responses from pupils in grade 12 were categorised as model 5 .

\section{SAMPLE}

The research reported here builds upon data from a two-and-a-half-year longitudinal study with student teachers enrolled in a teacher education programme for 3.5 years (7 terms) in science and mathematics for primary school (age 7-13) (Before 1988 primary school teachers in Sweden were educated to teach all subjects. Since 1988 they have been educated to teach a limited number of subjects). This study is part of larger study aiming at investigating how student teachers developed understanding of science and ability to reason about complex issues relevant for environmental education (Ekborg, 2005a,b).

All students who were accepted into the programme in one year were selected to participate in the study. They were followed through the regular programme, with no attempts from the researcher to interact or to introduce any changes in the programme.

\section{CURRICULUm}

In order to be accepted into the programme, students must have completed courses in natural sciences and mathematics at the upper secondary level. The teacher-training programme included science courses corresponding to at least 30 weeks of full time study. Besides these requirements the students took courses in mathematics, pedagogy, Swedish and optional courses. In addition, they wrote a dissertation paper and did school practice.

The science courses were organised as an integrated course of 10 weeks full time study in term 1 (NO1) and a 20 week full time course in term 4 and 5, organised as four separate courses of five weeks each physics, chemistry, human biology and technology (NO2). The content in NO1 included ecology, meteorology, astronomy and environmental issues. In this course the students worked in small groups with cases dealing with for example ecology and environmental issues, encountering concepts of greenhouse effect, the depletion of the ozone layer and combustion, as well as conservation of matter and energy. The learning objectives were that the students should 
Table 1. Students' explanations of what the greenhouse effect is in Andersson and Wallin (2000). The column "Key concepts" will be explained in the "Analysis" section.

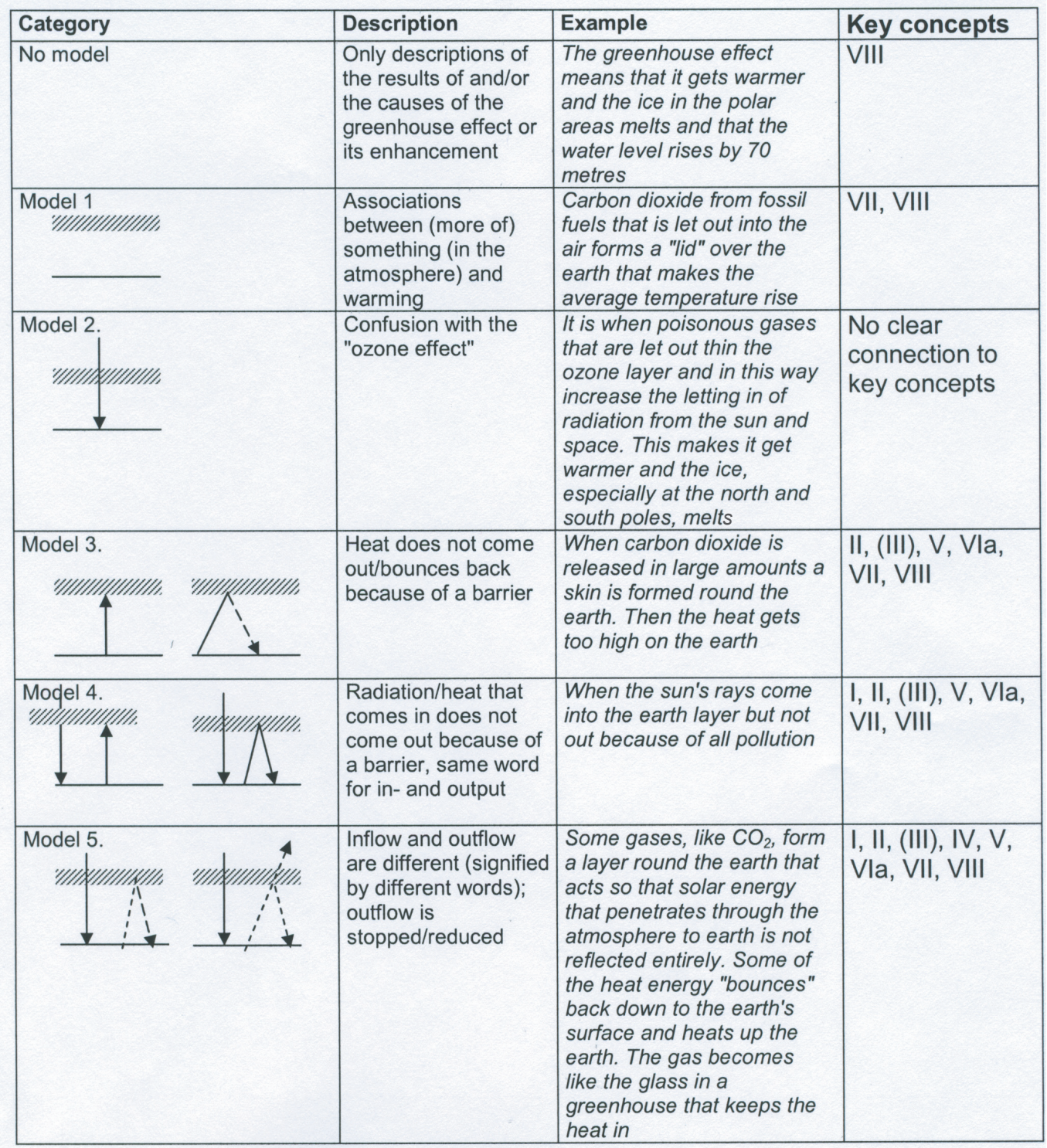

be able to describe the greenhouse effect, be able to separate between the greenhouse effect and depletion of the ozone layer and to know causes and consequences of the enhanced greenhouse effect. The focus was on natural science even if the concept was set up in a larger context.

In NO2 the physics course included a unit about environmental physics. The greenhouse effect was treated from a physical point of view. A few model calculations on earth temperature were carried out. Some experiments on absorption of IR-radiation were demonstrated. The students carried out laboratory work on combustion, energy release and carbon dioxide exhausts (Areskoug \& Ekborg, 2004). The objectives were to achieve understanding on basic physical concepts and relations concerning energy, energy transfer and energy balance. The general concepts were studied using environmentally relevant examples, e.g. the greenhouse effect. 


\section{DATA COLLECTION}

All student teachers answered a questionnaire three times - in the beginning of the programme, after NO1 and after NO2. 79 students started the programme and at the time of the third data collection 62 were still in the programme. The number of student teachers who answered the questionnaire was 60, 49 and 47 in the three questionnaires. The questionnaires were coded so that it was possible to compare individuals' development. In all questionnaires the students were given 12 statements about the greenhouse effect and the ozone layer. The students indicated if the statements were correct or not. The statements were taken from Boyes and Stanisstreet (1993) and Boyes, Stanisstreet and Chambers (1995). They were translated into Swedish and modified by the authors. In all three questionnaires the statements were the same but in different order.

The statements are on display in table 4 (subsection Results). All the statements were about causes and consequences of greenhouse effect and ozone depletion. The statements about the ozone layer were included, as it is known that it is common to confuse the greenhouse effect and ozone depletion. The first five statements test if the student teachers could separate the two problems.

In questionnaires 2 and 3 the student teachers also responded to the following question: "What is the greenhouse effect? Explain as well as you can".

\section{ANALYSIS}

The main scientific concepts and processes needed to understand the greenhouse effect may be presented in the following way:

I. The earth receives energy from the sun mainly in the form of visible light.

II. The earth emits energy to space in the form of infrared (IR) radiation.

III. The radiation may be absorbed by the atmosphere to a smaller or larger extent.

IV. Incoming and outgoing radiation may be affected in different ways by the atmosphere.

V. Different gases in the atmosphere have different abilities to absorb radiation. Some gases, greenhouse gases, absorb IR radiation strongly.

VI.

a. The absorbed energy causes a shift in the energy balance leading to a higher temperature in the atmosphere and on the earth by the following process:

b. The temperature of the atmosphere increases

c. The IR radiation emitted from the atmosphere increases. Some of it is directed down towards the earth. Energy is thus re-radiated.

$\mathrm{d}$. The earth receives and absorbs IR radiation from the atmosphere. The temperature of the earth increases.

VII. Combustion of fossil fuels causes a net increase of greenhouse gases (mainly carbon dioxide and water vapour) in the atmosphere.

VIII. Summary: Combustion of fossil fuels leads to an increased temperature on earth.

We think that the concepts VIb, VIc and VId have great importance. Many students in earlier investigations describe the greenhouse effect in terms of radiation "stopping" in the atmosphere or "bouncing back" to earth. The consequences of increasing concentration of greenhouse gases on earth temperature is mainly due to the fact that the absorption is displaced to atmospheric levels closer to the earth, thus causing higher temperature increase in a smaller air volume and with greater impact on the climate (Houghton, 2001). In order to understand this, the concepts VI b-d are crucial.

In a categorization of student answers, it is desirable that it is possible to make out these key concepts in order to discern different levels of understanding. 
Table 2. Categories for responses to the questions "What is the greenhouse effect? Explain as well as you can".

\begin{tabular}{|c|c|c|c|}
\hline $\begin{array}{l}\text { Cate- } \\
\text { gory }\end{array}$ & Description & Example & $\begin{array}{l}\text { Key } \\
\text { concepts }\end{array}$ \\
\hline 1 & $\begin{array}{l}\text { There are greenhouse } \\
\text { gases and/or the } \\
\text { temperature will rise. } \\
\text { In this category there } \\
\text { are examples of student } \\
\text { teachers that confuse the } \\
\text { greenhouse effect with } \\
\text { ozone depletion. }\end{array}$ & $\begin{array}{l}\text { The greenhouse effect depends on the fact that we } \\
\text { have an ozone layer leading to the outflow being } \\
\text { not as big as the inflow until there is equilibrium. } \\
\text { Therefore we get a temperature possible to } \\
\text { live in. Otherwise it would have been too cold } \\
\text { (questionnaire 3). }\end{array}$ & VII, VIII \\
\hline 2 & $\begin{array}{l}\text { The greenhouse effect is } \\
\text { due to the fact that the heat } \\
\text { outflow from the earth is } \\
\text { affected (prevented). } \\
\text { It is common that students } \\
\text { in this category describe } \\
\text { different kinds of lids, filters, } \\
\text { thick atmosphere etc. }\end{array}$ & $\begin{array}{l}\text { The carbon dioxide lies like a cover and the heat } \\
\text { radiates, so much of what is supposed to leave the } \\
\text { earth can not come out, but bounces back instead } \\
\text { (questionnaire 3). }\end{array}$ & $\begin{array}{l}\text { II, III, VII, } \\
\text { VIII }\end{array}$ \\
\hline 3 & $\begin{array}{l}\text { The inflow of energy (in the } \\
\text { form of light) is not affected } \\
\text { by the greenhouse gases, } \\
\text { while the outflow (in the form } \\
\text { of IR radiation) is affected. }\end{array}$ & $\begin{array}{l}\text { It works exactly as a greenhouse. There are certain } \\
\text { gases, which enclose heat on the earth. The } \\
\text { sunbeams come from the sun and hit the earth. } \\
\text { They are transformed into another wavelength } \\
\text { (heat rays). These cannot squeeze through the } \\
\text { greenhouse gases and whereby stay on the earth } \\
\text { (questionnaire 2). }\end{array}$ & $\begin{array}{l}I, I I, I I I, I V \\
\text { VII, VIII }\end{array}$ \\
\hline $4 a$ & $\begin{array}{l}\text { The IR radiation is absorbed } \\
\text { in the greenhouse gases } \\
\text { whereby the temperature on } \\
\text { earth increases }\end{array}$ & $\begin{array}{l}\text { The greenhouse effect is a prerequisite for life on } \\
\text { earth. If it did not exist there would have been a } \\
\text { temperature of }-18{ }^{\circ} \mathrm{C} \text {. The sun radiates in towards } \\
\text { the earth, the earth radiates out in order to reach } \\
\text { equilibrium. The atmosphere absorbs the radiation } \\
\text { and multi-atomic molecules such as } \mathrm{CO}_{2} \text { and } \\
\mathrm{H}_{2} \mathrm{O} \text { absorb more as they are dipoles. The kinetic } \\
\text { energy increases in these molecules and the } \\
\text { temperature in the atmosphere increases whereby } \\
\text { (questionnaire 2). }\end{array}$ & $\begin{array}{l}I I, I I, \text { V, } \\
\text { VIa, VII, } \\
\text { VIII }\end{array}$ \\
\hline $4 b$ & $\begin{array}{l}\text { The IR radiation is absorbed } \\
\text { in the greenhouse gases } \\
\text { whereby the temperature on } \\
\text { earth increases. Inflow and } \\
\text { outflow are different }\end{array}$ & $\begin{array}{l}\text { Some light rays from the sun reach the surface of } \\
\text { the earth. Then the light rays are energy-rich. The } \\
\text { radiation gives energy to the earth. Some of the } \\
\text { heat rays are absorbed by the greenhouse gases } \\
\text { and some are reflected back to the surface of the } \\
\text { earth. The atmosphere does not let the energy poor } \\
\text { radiation out as easily as the energy rich radiation } \\
\text { (questionnaire 2). }\end{array}$ & $\begin{array}{l}\text { I, II, III, IV, } \\
\text { V, VIa, VII, } \\
\text { VIII }\end{array}$ \\
\hline
\end{tabular}




\begin{tabular}{|c|c|c|c|}
\hline $5 a$ & $\begin{array}{l}\text { The IR radiation is absorbed } \\
\text { in the greenhouse gases, } \\
\text { which re-radiate towards } \\
\text { the earth whereby the } \\
\text { temperature of the earth } \\
\text { increases }\end{array}$ & $\begin{array}{l}\text { Is formed when the earth's heat radiation is } \\
\text { absorbed by the atmosphere. About half of the } \\
\text { earth's heat radiation is sent out into space and half } \\
\text { of it back to the earth. As much energy as the earth } \\
\text { gets from the sun is sent out as heat radiation. If } \\
\text { the greenhouse gases increase in the atmosphere } \\
\text { the absorption and the re-radiation will increase } \\
\text { (questionnaire 3). }\end{array}$ & $\begin{array}{l}\text { II, III, V, } \\
\text { Vlabd, VII, } \\
\text { VIII }\end{array}$ \\
\hline $5 b$ & $\begin{array}{l}\text { The IR radiation is absorbed } \\
\text { in the greenhouse gases, } \\
\text { which re-radiate towards } \\
\text { the earth whereby the } \\
\text { temperature of the earth } \\
\text { increases. Inflow and } \\
\text { outflow are different. } \\
\text { Responses including the } \\
\text { concept reflection are not } \\
\text { categorised in this category }\end{array}$ & $\begin{array}{l}\text { Greenhouse gases in the atmosphere (e.g. carbon } \\
\text { dioxide) absorb heat radiation from the earth. } \\
\text { The sun radiates "short wave-lengths" towards } \\
\text { the earth. The earth radiates out long wavelength } \\
\text { radiation. This radiation is absorbed by e.g. carbon } \\
\text { dioxide. The greenhouse gases in their turn } \\
\text { radiates out heat towards both the space and the } \\
\text { earth. Therefore the temperature goes up. Negative } \\
\text { greenhouse effect is when we disturb the balance } \\
\text { e.g. combust fossil fuels (questionnaire 3). }\end{array}$ & $\begin{array}{l}\text { I, II, III, IV, } \\
\text { V, VIabd, } \\
\text { VII, VIII }\end{array}$ \\
\hline 6 & $\begin{array}{l}\text { The temperature on earth } \\
\text { is decided by a dynamic } \\
\text { balance, where the point } \\
\text { of balance is affected } \\
\text { by among other things } \\
\text { the absorption in the } \\
\text { greenhouse gases }\end{array}$ & No example available & $\begin{array}{l}\text { I, II, III, IV, } \\
\text { V, Vlabcd, } \\
\text { VII, VIII }\end{array}$ \\
\hline
\end{tabular}

The categorization developed by Andersson and Wallin (2000) was tried as a starting point. It worked quite well in describing the answers of the second questionnaire. But in the third questionnaire several students described the greenhouse effect in terms of emission, absorption and re-radiation, some of them also pointing out the difference between incoming and outgoing radiation. In the categorization by Andersson and Wallin (2000) the key concepts revealed are indicated in the right column in table 1.The parenthesis on concept III indicates that it is not always clear whether the student means absorption or reflection. From table 1 it is obvious that the categorization does not discern the processes of absorption and re-radiation in the atmosphere (the key concepts VI b, c, $\mathrm{d}$ are not discovered).

Therefore we have, starting from Andesson and Wallin (2000), developed new categories shown in table 2 . The main difference between category $4 \mathrm{a}$ and $\mathrm{b}$ as well as $5 \mathrm{a}$ and $\mathrm{b}$ is that the $\mathrm{b}$ responses include a statement about the difference between incoming and outgoing radiation. In each category an example illustrates typical responses. All excerpts are translated into English by the authors.

\section{RESULTS}

\section{Statements}

Table 3 shows the average number of correct answers given by the students. The number increased after the first science course (questionnaire 2) but not after the second science course (questionnaire 3). The results of the individual statements (table 4) indicate that virtually all students learnt that the greenhouse effect is crucial for life on earth. A majority of the students learnt to separate 
between the greenhouse effect and ozone depletion in the first science course. Most students understood some causes and consequences of the greenhouse effect and ozone depletion. However most students still believed that driving a car with a catalyst will decrease global warming. But most of them did not believe that driving with lead free petrol would have the same impact. To two questions about the greenhouse effect there were a substantial decrease in the number of correct answers in questionnaire 3 compared to questionnaire 2. Both were about CFC's and their role as greenhouse gases (statement 4 and 11).

Table 3. The number of correct responses to 12 statements about the greenhouse effect. Mean value for the student teachers in the three questionnaires.

\begin{tabular}{|c|c|c|}
\hline $\begin{array}{c}\text { Questionnaire 1, } \\
\mathrm{n}=60\end{array}$ & $\begin{array}{c}\text { Questionnaire 2, } \\
\mathrm{n}=49\end{array}$ & $\begin{array}{c}\text { Questionnaire 3, } \\
\mathrm{n}=47\end{array}$ \\
\hline 5,8 & 8,0 & 7,4 \\
\hline
\end{tabular}

Table 4. The percentage of student teachers who ticked the statements correctly. Correct statements are in bold text.

\begin{tabular}{|c|c|c|c|c|}
\hline & \multirow[b]{2}{*}{ Statement } & \multicolumn{3}{|c|}{ Percentage of correct answers } \\
\hline & & $\begin{array}{l}\text { Questionnaire } \\
\qquad 1 \mathrm{n}=60\end{array}$ & $\begin{array}{l}\text { Questionnaire } \\
\qquad 2 \mathrm{n}=49\end{array}$ & $\begin{array}{l}\text { Questionnaire } \\
\qquad 3 n=47\end{array}$ \\
\hline 1 & $\begin{array}{l}\text { If the holes in the Ozone Layer get worse the } \\
\text { Greenhouse Effect will get worse }\end{array}$ & 25 & 67 & 66 \\
\hline 2 & $\begin{array}{l}\text { Holes in the Ozone Layer are made worse by } \\
\text { emission of carbon dioxide }\end{array}$ & 31 & 67 & 68 \\
\hline 3 & $\begin{array}{l}\text { Holes in the Ozone Layer are made worse by } \\
\text { gases called CFCs }\end{array}$ & 66 & 80 & 98 \\
\hline 4 & $\begin{array}{l}\text { The Greenhouse Effect is made worse by } \\
\text { emission of CFCs }\end{array}$ & 56 & 71 & 36 \\
\hline 5 & $\begin{array}{l}\text { If the Greenhouse effect gets bigger more } \\
\text { people will get skin cancer }\end{array}$ & 49 & 82 & 70 \\
\hline 6 & $\begin{array}{l}\text { The Greenhouse Effect can be decreased by } \\
\text { having more nuclear power stations instead } \\
\text { of coal power stations }\end{array}$ & 71 & 90 & 89 \\
\hline 7 & $\begin{array}{l}\text { The Greenhouse Effect can be decreased by } \\
\text { using unleaded petrol }\end{array}$ & 37 & 45 & 62 \\
\hline 8 & $\begin{array}{l}\text { If there was no Greenhouse Effect there } \\
\text { would be no life on Earth }\end{array}$ & 52 & 96 & 94 \\
\hline 9 & $\begin{array}{l}\text { If the Greenhouse effect is enhanced there will } \\
\text { be more earthquakes }\end{array}$ & 73 & 55 & 60 \\
\hline 10 & $\begin{array}{l}\text { If the Greenhouse effect is enhanced there } \\
\text { will be more "bugs" and "pests" on crops }\end{array}$ & 58 & 73 & 68 \\
\hline 11 & $\begin{array}{l}\text { The Greenhouse Effect is enhanced by too much } \\
\text { ozone near the ground }\end{array}$ & 47 & 67 & 17 \\
\hline 12 & $\begin{array}{l}\text { If all cars had catalysts the Greenhouse Effect } \\
\text { would be reduced }\end{array}$ & 15 & 17 & 17 \\
\hline
\end{tabular}


Table 5. The student teachers' responses to the question "What is the greenhouse effect? Explain as well as you can". The categories are developed by the authors. All entries are percentage.

\begin{tabular}{|l|c|c|}
\hline \multirow{2}{*}{$\begin{array}{l}\text { Category } \\
\text { (see table 2) }\end{array}$} & \multicolumn{2}{|c|}{ Percentage of answers } \\
\cline { 2 - 3 } & $\begin{array}{c}\text { Questionnaire 2 } \\
\mathrm{n}=49\end{array}$ & $\begin{array}{c}\text { Questionnaire 3 } \\
\mathrm{n}=47\end{array}$ \\
\hline 1 & 22 & 17 \\
\hline 2 & 27 & 28 \\
\hline 3 & 37 & 15 \\
\hline $4 \mathrm{a}$ & 4 & 11 \\
\hline $4 \mathrm{~b}$ & 10 & 4 \\
\hline $5 \mathrm{a}$ & 0 & 19 \\
\hline $5 \mathrm{~b}$ & 0 & 6 \\
\hline 6 & 0 & 0 \\
\hline
\end{tabular}

\section{Description of the greenhouse effect}

The result from the open-ended question, "What is the greenhouse effect? Explain as well as you can", is displayed in table 5. A response placed in categories 3-6 is considered as demonstrating a basic understanding of the greenhouse effect. Already in questionnaire 2, after the first science course (NO1), half (51\%) of students' responses were placed in category 3 or above. In questionnaire 3 , after the second science course (NO2) $55 \%$ of the responses were categorised as 3 or above. 40\% introduced absorption and/or re-radiation in the responses compared to 14\% in questionnaire 2. However several student teachers who described the difference between incoming and outgoing radiation in questionnaire 2 did not in questionnaire 3.

Looking at individuals only 5 students whose responses were categorised as category 1 or 2 in questionnaire 2 (i.e. 5 out of 24 students) developed so that their responses were categorised as category 3 or above in questionnaire 3 . The rest stayed in the lower categories. It seems as if the students who developed a more complex understanding in the second science course were those who already had reached a basic understanding (category 3 or above). Only one student gave a response in questionnaire 3, which was categorised in a lower category than in questionnaire 2 (cat 3-cat 2). None of the students' responses were categorised as category 6.

As a comparison table 6 shows the student teachers' responses when we used the models developed by Andersson and Wallin (2000). Then the result shows that the student teachers' understanding of the greenhouse effect declined in questionnaire 3. On the other hand, if we use our categorising the student teachers' understanding improved in questionnaire 3.

\section{Discussion}

Half of the student teachers (55\%) developed an adequate understanding of the greenhouse effect during the teaching programme. As "adequate understanding" we judge, in this context, knowing that infrared radiation from the earth is absorbed in the atmosphere by greenhouse gases from fossil fuels, causing increased temperature (key concepts II, III, VII and VIII), deepened by knowing that incoming and outgoing radiation are affected in different ways (concepts I and IV), and / or that different gases have different abilities to absorb radiation, leading to a shift in the energy balance (concepts V and VIa). 
Table 6. The student teachers' responses to the question "What is the greenhouse effect? Explain as well as you can". The responses are categorised using the models developed by Andersson and Wallin (2000). All entries are percentages.

\begin{tabular}{|c|c|c|}
\hline \multirow{2}{*}{ Model } & \multicolumn{2}{|c|}{ Percentage of answers } \\
\cline { 2 - 3 } & $\begin{array}{c}\text { Questionnaire 2 } \\
\mathrm{n}=49\end{array}$ & $\begin{array}{c}\text { Questionnaire 3 } \\
\mathrm{n}=47\end{array}$ \\
\hline 0 & 2 & 0 \\
\hline 1 & 6 & 6 \\
\hline 2 & 4 & 9 \\
\hline 3 & 20 & 41 \\
\hline 4 & 18 & 23 \\
\hline 5 & 49 & 23 \\
\hline
\end{tabular}

Several of the students developed their understanding further in the second science course. However a majority of students with poor understanding did not develop any further in the second science course and no one demonstrated full understanding as described in category 6 . In the following subsection some of the difficulties in measuring students' understanding will be discussed as well as the effect of teaching.

\section{Consistency between statements and model}

For most students the number of correctly marked statements corresponded fairly well with the model of the greenhouse effect described in their own words. Students who ticked most statements correctly also described an adequate model. Students with few correctly marked statements often showed misconceptions about the greenhouse effect in the descriptions. But there were five students that ticked at least nine statements correctly and still gave descriptions of the greenhouse effect that were categorised as category 1 or 2 . There were 8 students who described the greenhouse effect in category 4 or above and only marked 7 statements or less correctly. It may be remarked, that some of these incorrectly marked statements (number 9, 11, 12) do not concern the major processes of the greenhouse effect. Apparently it is possible to give a good description of the greenhouse effect and carry an alternative parallel understanding. Some of the statements are quite tricky and it is often necessary to think in several steps to judge what is correct or not. It might be that the students quickly responded. In that case there is a risk that you measure what is memorised instead of more complex understanding.

Also some statements may seem a bit misleading. In an interview attendant questions may have revealed the students' thinking more inconsistently. The first thing to understand about the greenhouse effect and the ozone depletion is that they are different phenomena, which should not be confused. Maybe that is why several students tick "no" to statement 4, knowing that the CFC gases are greenhouse gases but not the principal cause of the enhanced greenhouse effect. Also, statement 8 may seem too strong to be regarded as true. In this case, however, almost every student accepts the statement in questionnaires 2 and 3. Statement 2 may be considered as partly true. By enhanced greenhouse effect the absorption of IR- radiation is displaced to lower levels of the atmosphere. The intensity of IR and thus the absorption at higher levels is decreased, leading to a lower temperature at higher levels, which in turn stimulates ozone depletion.

\section{Using appropriate categories}

Depending on what categorisations, the student teachers' understanding can be interpreted in different ways. Below some excerpts demonstrate how responses can be interpreted depending on the category system used. 
If the categories, developed by Andersson and Wallin (2000) are used, the following response would be categorised as model 3 (table 1). Using our categories the response is categorised as $5 \mathrm{a}$ (table 2). Absorption is included and "sends back" is interpreted as re-radiation. The response does not include anything about incoming radiation though.

The greenhouse gases, $\mathrm{CO}_{2}$, absorb long wave radiation and sends it back to the earth which in its turn increases the temperature when there are huge emissions of greenhouse gases. (questionnaire 3).

The following excerpts from one student show that the categories by Andersson and Wallin (2000) are too limited to fully describe the student's understanding. Using this category system would mean that both responses would be categorised as model 5 (table 1). Using our categories puts the first excerpt (questionnaire 2) in category 3 and the second (questionnaire 3 ) in category 5b thus showing a conceptual development (table 2).

Greenhouse gases: Carbon dioxide, CFC, dinitrogen oxide. NOx etc. The short wave radiation goes through the atmosphere while the long wave radiation is hold back. This results in increased temperature. Compare with a greenhouse. In industrial combustion carbon dioxide is formed. The greenhouse effect is enhanced. (questionnaire 2).

Greenhouse gases in the atmosphere (e.g. carbon dioxide) absorb heat radiation from the earth. The sun sends short wave radiation towards the earth. The earth radiates heat. This radiation is absorbed by e.g. carbon dioxide. The greenhouse gases radiate heat towards both the space and the earth. Therefore the temperature increases. There is a negative greenhouse effect if we disturb the balance by e.g. combustion of fossil fuels. (questionnaire 3).

In our categorisation we have chosen to categorise responses in a high category even if they do not include statements about the difference between incoming and outgoing radiation. This can of course be discussed. In the example above it is reasonable to believe that this person knows about the difference even if it is not explicitly expressed in the second quotation. In the first quotation the student teacher demonstrates that she has this knowledge and as her response is more advanced in the second questionnaire it is reasonable to interpret the wave-length shift is self-evident to the student teacher. But it raises a number of questions concerning how to interpret students' understanding from written responses. How does the way the categorising is done affect the judgement of the student's knowledge?

\section{Teaching and learning}

The students in this study showed misconceptions to less extent compared to earlier studies (Boyes \& Stanisstreet, 1992, Jeffries, Stanisstreet \& Boyes, 2004, Kahlid, 2003, Dove, 1996 and Andersson \& Wallin, 2000). Unlike the other studies it was certain that the students in this study had been taught about the greenhouse effect. The teaching was consciously planned to overcome wellknown problems in understanding the greenhouse effect. However it is difficult to draw conclusions about the effect of teaching. There are many factors that can influence the student teachers' learning. These students are for example older than most of the students in other studies. There is some inconsistency between the responses to the tic box questions and the open-ended question

After the first science course, $47 \%$ of students described the difference between incoming and outgoing radiation of energy in terms of different wavelengths. After the second science course only $25 \%$ did so even if they described more advanced models. The students might respond in a way, which is close to the content of their latest course. In the first science course the greenhouse effect was treated in a context in which there was an emphasis on a basic model described as model 5 by Andersson and Wallin (2000). In the second science course there was emphasis on model 
calculations on the energy balance including the sun, the earth and the atmosphere. Although the wavelength shift was discussed it never reached the equations based on emitted energy according to Stefan-Boltzmanns law. As these equations caused the students a lot of problems, it may seem probable that they did not pay much attention to the wavelength shift.

\section{Implications for teaching}

In teacher education it is important to include issues about major environmental issues, which are important to our future. These students are to teach young pupils in school helping them to be able to understand debates in society and to make decisions based on sound science. In successful teacher education there is need to connect different courses to each other. There should be a follow up so that the teachers make sure that their students have understood the basic elements before continuing to the next step. In a more advanced course there is also a need to connect the new concepts to what has been taught earlier so that the students may develop their understanding further instead of replacing one model with another.

In the beginning of this paper we state that you need to understand the effects of burning fossil fuels on climate to be able to follow and participate in the debate concerning these issues, and to be able to make decisions and articulate your opinion and act in accordance with this. In this paper we have concentrated on the conceptual understanding of the greenhouse effect. We believe that it is important that decision-making is done on basis of sound science. But that is of course not enough. The student teachers need to work with authentic issues in which they must scrutinize information and values underpinning arguments. They must get guidance in connecting scientific knowledge to real life situations (Ekborg 2005a, 2005b).

\section{REFERENCES}

Andersson, B., \& Wallin, A. (2000). Students' understanding of the greenhouse effect, social consequences of reducing $\mathrm{CO}_{2}$ emissions and why ozone layer depletion is a problem. Journal of Research in Science Teaching, 37(10), 1096-1111.

Areskoug, M., \& Ekborg, M. (2004). Experiments for understanding the greenhouse effect. In P. Wickenberg, H. Axelsson, L. Fritzén, G. Helldén \& J. Öhman (Eds.), Learning to change our world? Swedish research on education \& sustainable development. Lund: Studentlitteratur.

Boyes, E., \& Stanisstreet, M. (1997). The Environmental Impact of Cars: children's ideas and reasoning. Environmental Education Research, 3(3), 269-228.

Boyes, E., Chambers, W., \& Stanisstreet, M. (1995). Trainee primary teachers' ideas about the ozone layer. Environmental Education Research, 1(2), 133-144.

Boyes, E., \& Stanisstreet, M. (1992). Students' perceptions of global warming. International Journal of Environmental Studies, 42, 287-300.

Boyes, E., \& Stanisstreet, M. (1993). The Greenhouse Effect: children's perceptions of causes, consequences and cures. International Journal of Science Education, 15(5), 531-552.

Boyes, E., \& Stanisstreet, M. (1998). High school students' perception of how major global environmental effects might cause skin cancer. The Journal of Environmental Education, 29(2), 21-36.

Dove, J. (1996). Student Teachers' Understanding of the Greenhouse Effect, Ozone Layer Depletion and Acid Rain. Environmental Education Research, 2(1), 89-100.

Ekborg, M. (2005a). Student-teachers' Learning Outcomes during Science Subject Matter Courses. International Journal of Science Education, 27(14), 1671-1694.

Ekborg, M. (2005b). Is heating generated from a crematorium an appropriate source for district heating? Student teachers reasoning about a complex environmental issue. Environmental Education Research, 11(5), 557-573. 
Houghton, J.T. (2001). Climate change 2001: the scientific basis: contribution of Working Group I to the third assessment report of the Intergovernmental Panel on Climate Change. New York: Cambridge University Press.

Jeffries, H., Stanisstreet, M., \& Boyes, E. (2004). Knowledge about the "Greenhouse effect": have college students improved? Research in Science \& Technological Education, 19 (2), 200221.

Khalid, T. (2003). Pre-Service High School Teachers' Perceptions of Three Environmental Phenomena. Environmental Education Research, 9(1), 35-50.

Mason, L., \& Santi, M. (1998). Discussing the Greenhouse Effect: children's collaborative discourse reasoning and conceptual change. Environmental Education Research, 4(1), 67-85.

QCA, Qualification and Curriculum Authority. Education for sustainable development. Available: http://www.nc.uk.net/esd/teaching/science/index.htm [2006, 06-05].

Rickinson, M. (2001). Learners and Learning in Environmental Education: a critical review of the evidence. Environmental Education Research, 7(3), 207-316.

Skolverket, The national agency for education. (2000). Syllabuses for the Compulsory school, Available: http://www.skolverket.se/sb/d/493/a/1303 [2006, 06-05]. 